infection in childhood to provide immunity to toxoplasmosis for pregnant women.

1 Fleck DG. Toxoplasmosis. Public Health (London) 1969;83:131-5.

2 Masur H, Jones TC, Lempert JA, Cherubini TD. Outbreak of toxoplasmosis in a family and documentation of acquired retinochoroiditis. Am ₹ Med 1978;64:396-402.

${ }^{3}$ Desmonts G, Couvreur J, Alison F, Baudelot J, Gerbeaux J, Lelong $M$. Étude épidemiologique sur la toxoplasmose: de l'influence de la cuisson des viandes de boucherie sur la fréquence de l'infection humaine. Revue Francaise d'Etudes Cliniques et Biologiques 1965;10:952-8.

${ }^{4}$ Fleck DG, Kwantes W. The laboratory diagnosis of toxoplasmosis. Public Health Laboratory Service Monograph Series No 13. London: HMSO, 1980.

\section{Children born as a result of incest}

After an address to the Medicolegal Society on the crime of incest, Sir Desmond Ackner" asked, "To what extent is it a serious eugenic risk if brother and sister marry ?" There was no response from his audience. Father-daughter and brothersister unions result in inbreeding four times as intense as in first-cousin marriages. The surveys of the extra risks of recessive disorders and congenital malformations to the children of first cousins have not, however, given enough information to permit reliable extrapolation to the children of incestuous unions. There are also obvious difficulties in following up closely children born to a random sample of incestuous unions without causing distress to the families.

Nevertheless, three studies have been reported. The largest, a retrospective survey of 161 children, was from Czechoslovakia $^{2}$ in 1971. Rare recessive or probably recessive disorders found in the children included homocystinuria, adiposogenital syndrome, congenital ichthyosis, retinitis pigmentosa, and deaf-mutism as well as a high incidence of mental retardation. Fewer than half the children were normal. This study might possibly have been biased by some selection in the sources from which the children were ascertained. The other two studies, ${ }^{3}{ }^{4}$ one from England of 13 live-born children followed up for four to six years and one from Michigan of 18 live-born children followed up for six to 12 years, were prospective, with the children being ascertained during their mothers' pregnancies.

Of the 31 children in these two studies-12 born to fatherdaughter and 19 to brother-sister matings-only 13 were normal. Two died from recessive disorders (cystic fibrosis and glycogen-storage disease) and one from an almost certainly recessive disorder causing progressive cerebral degeneration and loss of vision. Two of those alive probably had recessive disorders, both with severe mental retardation with cerebral palsy, and one a possibly recessive disorder, severe non-specific mental retardation. Two others had died in the neonatal period, a baby with very low birth weight and another with respiratorydistress syndrome. Two had congenital malformations, a lethal Fallot's tetralogy and a survivor with bilateral cleft lip. Eight other survivors were mildly mentally retarded with IQs in seven ranging from 59 to 76; the eighth, whose IQ score was not available, was in a school for the educationally subnormal.

This increase in recessive disorders-between three and six cases in 31 children compared with an expected incidence 5 in the general population of two or three per thousand-is in line with expectations. It is compatible with a lesser increase in the children of first cousins, and with the average person carrying one or two recessive genes which when homozygous will cause a serious disorder in live-born children. The average person may well carry further recessive genes which when homozygous will cause early death in utero; but there are no good data on this.

A relatively smaller increase in common congenital malformation, two cases in 31 children compared with about $2 \%$ in the general population, ${ }^{6}$ is also what might be expected. Inbreeding increases the variance of the genetic liability to multifactorial conditions. The increased incidence of mild mental retardation is also noteworthy. It did not, at least in the American series, simply reflect the low level of intelligence of the biological parents. Some lowering of $\mathrm{IQ}$, of less degree, has been found in the offspring of first cousins both from Japan $^{7}$ and from Arabs in Israel. ${ }^{8}$ New prospective studies are needed from northern Europe and North America of the children of both incestuous unions and first-cousin marriages, making use of modern clinical and biochemical screening for recessive disorders-though these would not be easy to arrange. On the present evidence the risks to the children of father-daughter and brother-sister unions, in contrast to those of first-cousin marriages, seem unacceptable. The risks are probably also unacceptably high in the intermediate case of uncle-niece, half sister-half brother, and double first-cousin marriages-except perhaps in communities where a long tradition of close inbreeding has substantially lowered the carrier prevalence of recessive genes.

1 Ackner Sir Desmond. The crime of incest. Med Leg 7 1980;48:79-91.
2 Seemanova E. A study of incestuous mating. Hum Hered $1971 ; 21: 108-28$.
3 Carter CO. Risk to offspring of incest. Lancet $1967 ; 1: 436$.
4 Adams MS, Neel JV. Children of incest. Pediatrics $1967 ; 40: 55-62$.
5 Carter CO. Monogenic disorders. F Med Genet $1977 ; 14: 316-20$.
Leck I. Congenital malformations and childhood neoplasms. F Med Genet
1977;14:321-6.
Schull WJ, Neel JV. The effect of inbreeding on Fapanese children. New
York: Harper and Row, 1965 .
${ }^{8}$ Bashi J. Effect of inbreeding on cognitive performance. Nature 1977; Bashi J. Effect
:440-2.

\section{Colposcopy}

When Hinselmann ${ }^{12}$ first described the colposcope 50 years ago cervical cancer was thought to begin as an invasive lesion in a small focus or nodule. The colposcope was meant to help the human eye identify this first, cancerous spot. For many years descriptions of the instrument and its use were confined to German publications, where a highly specialised and cumbersome colposcopic terminology developed which had little appeal to the English-speaking world. ${ }^{3}$ In time Papanicolau's description ${ }^{4}$ of exfoliative cytology, and a growing awareness of the widespread, subtle, cellular changes within the cervical epithelium that precede invasive cancer, focused the attention of gynaecologists on cervical cytology rather than on colposcopy. This led to more frequent use of cone biopsy-on receipt of a positive cervical smear gynaecologists wanted the pathologist to differentiate between dysplasia, carcinoma-in-situ, and microinvasive or invasive cancer of the cervix. ${ }^{5}$

In North America ${ }^{5}$ and in Britain ${ }^{6}$ the investigation and management of patients with abnormal cervical smears have recently taken a new turn with the reappearance of colposcopy as a technique that bridges the gap between Papanicolau-smear screening and definitive histological diagnosis. Coppleson has 